\title{
Influence of selection phase, fasting and transport on porcine stress and on the development of PSE pork
}

\author{
MARKKU HONKAVAARA \\ Finnish Meat Research Centre, Box 56, \\ SF-13101 Hämeenlinna, Finland
}

\begin{abstract}
The objectives were to investigate the effect of selection phase, fasting time and transportation on porcine stress and on the occurrence of pale, soft and exudative (PSE) pork.

The first selected pigs had the lowest blood creatine kinase (CK) activity and were least susceptible to PSE development. Whereas, the second selected animals were most stressed during transport and showed the highest frequency of PSE. On the other hand, the last selected pigs had elevated CK values from the farm up to stunning, and also showed a slow $\mathrm{pH}$ fall in M. longissimus dorsi (LD) 45 min postmortem (p.m.). Furthermore, the pigs of the first and last selection had, respectively, the lowest and highest lean meat content.

Muscle traits such as glycogen and lactate content 0 min p.m. and pH 45 min p.m. suggested that the most acceptable pork quality for meat products manufacture could be obtained after a fast of $6-7 \mathrm{~h}$ if the pigs were fed twice a day. Whereas, overnight holding had a negative effect on muscle glycogen and lactate content.

During transport, pigs were under greatest stress if they were loaded just before feeding period, or if they were transported in warm weather (over $10^{\circ} \mathrm{C}$ ). Moreover, high mortality and $\mathrm{CK}$ values occurred at the same external temperatures during transportation. In addition, increased transport time elevated the $\mathrm{CK}$ activity from the farm up to the abattoir.
\end{abstract}

Index words: selection phase, fasting, transport, creatine kinase, PSE meat

\section{Introduction}

Pigs fed a restricted ration twice a day showed much more variation in glucose flux rate, rate of formation and hydrolysis of glycogen than pigs fed ad libitum (Rıs and Grummer, 1969). Easily mobilized glycogen stores were exhausted in about $20 \mathrm{~h}$. Pigs fed ad libitum most likely had an almost constant glycogen reserve, whereas the labile glycogen depots of pigs fed a restricted ration were presumably nearly exhausted in the morning before feeding (RIIS and Grummer, 1969). POSPIECH et al. (1981) observed that the highest number of pigs with muscle defects of PSE and DFD type occurred in groups of 90 
and $120 \mathrm{~kg}$ live-weight. Lower meat quality was perhaps caused by the change in metabolism. In the group of $90 \mathrm{~kg}$ it was probably connected with the change of proteins to carbohydrates proportion in the fodder. The cause of the poorer meat quality of $120 \mathrm{~kg}$ pigs could be the slowing down of muscle tissue synthesis (PosPiech et al., 1981).

For practical purposes only those factors which affect energy reserves in the muscle at the point of slaughter were important for meat quality (BARTON-GADE, 1985). If PSE and DFD meat were considered equally important, then slaughter of unfed pigs immediately after unloading and slaughter of fed pigs after a holding period of about four hours gave the lowest frequency of both PSE and DFD (NIELSEN, 1981). Withholding food during the 12-hour period prior to transportation was a simple way to reduce death during transport (Williams, 1985).

Earlier work (HonkavaARA, 1989) considered the influence of porcine stress on blood composition and early p.m. meat quality in pigs of different halothane genotypes. The purpose of this study was to investigate the effects of selection phase, fasting time and transportation of porcine stress and meat quality. In addition, it was studied the effect of transport temperature and time on mortality of pigs.

\section{Material and methods}

\section{Test animals}

The test animals consisted of 103 pigs of which one died during transport. They were from the following breeds: 39 Finnish Landrace $(\mathrm{L})$ and 8 Finnish Yorkshire $(\mathrm{Y})$ pigs, and $56 \mathrm{LxY}$ crosses. 11-12 pigs were collected per month from September 1985 to May 1986. 31, 12,8 and 4 pigs came respectively from 1,2 , 2 and 8 producers. Treatments were repeated 22 times, and the programme of one treatment is described earlier (HonkavaAra, 1988). 28, 24 and 50 pigs were slaughtered at the abattoir in Nurmo, Forssa and Salo, respectively.
The pigs were selected in three phases. Thus the animals of the first, second and last selection gained the slaughter weight of $90-120 \mathrm{~kg}$ first, second and third, respectively. Farmers evaluated the weight of pigs by measuring or weighing. After blood sampling, marking and tattooing, the test animals were not separated from other pigs at farm. Moreover, all pigs were treated in the same way from the farm up to the point of stunning. Furthermore, data were collected from the last feeding time of day, loading time of day, transport temperature and duration.

In order to compare the influence of transport temperature and time on mortality with the CK values of the test pigs after transport, data were collected from a further 317 pigs which have died in trucks in 1986.

\section{Evaluation of porcine stress and meat quality}

Methods used for the evaluation of porcine stress and meat quality are presented earlier (Honkavaara, 1988).

\section{Variables}

The collected data included the following 20 continuous variables: loading time of day (LT), transport temperature (TT), transport duration (TD), duration of lairage (DL), temperature of lairage (TL), humidity of lairage (HL), stunning time of day (ST), fast duration (FD, time elapsed between feeding and stunning), carcass temperature 0 min p.m. $\left(\mathrm{CT}_{0}\right)$, blood creatine kinase (CK) activity on farm (CKF), CK activity during unloading (CKU), CK activity at exsanguination (CKE), serum glucose (SG), serum glycerol (SGL), serum lactate $(\mathrm{SL})$, serum $\mathrm{pH}(\mathrm{SpH})$, muscle glycogen 0 min p.m. $\left(\mathrm{MG}_{0}\right)$, muscle lactate 0 min p.m. $\left(\mathrm{ML}_{0}\right), \mathrm{pH}$ in the $M$. longissimus dorsi (LD) 45 min p.m. $\left(\mathrm{pH}_{1}\right)$ and carcass hot weight $(\mathrm{CW})$. Also carcass grading class (CC) was included as an uncontinuous varia- 
ble in the analysis. The CKF, CKU and CKE values were $\log _{10}$ transformed.

\section{Statistical analyses}

Conventional statistical methods were used to calculate means, standard deviations and standard error of the means (SEM). In order to examine significant relations between the variables and differences among the means, data were analysed by simple regression and by analysis of variance, respectively. Furthermore, to evaluate the influence of the variables on porcine stress and meat quality, a stepwise linear regression analysis was performed (statistical program Pato for microcomputers, Mikrovuo Ky, Finland).

The regression model (1) included the dependent variable $Y_{i}(i=1-9)$, the 20 independent variables $X_{j}(j=1-20, j \neq i)$ and the standardized regression coefficients $B_{j}$ $(j=1-20, j \neq i)$.

$$
\mathrm{Y}_{\mathrm{i}}=\mathrm{B}_{1} \mathrm{X}_{1}+\mathrm{B}_{2} \mathrm{X}_{2}+\mathrm{B}_{3} \mathrm{X}_{3}+\ldots+\mathrm{B}_{20} \mathrm{X}_{20}
$$

Regression analysis computed the combination of the most contributing independent variables to the regression model. The program added to the model that variable which fulfilled the F-ratio criterion $(F>3)$ and had the maximum coefficient of determination $\left(\mathrm{R}^{2}\right)$. The variables which made minor contributions $(\mathrm{F}<2)$ were deleted from the model. Finally the program printed the chosen model which estimated the dependent variable best. This output included the coefficient of determination, F ratio, significance of contribution, chosen independent variables and their standardized regression coefficients, partial regression coefficients, $F$ values, significance levels and contributions.

On the basis of stepwise regression, the prediction equations (2) were developed using the independent variables described above.

$$
\begin{aligned}
Y_{i}= & B_{0}+B_{1} X_{1}+B_{2} X_{2}+\ldots+B_{n} X_{n} \\
& (i=1-9, n=3-5)
\end{aligned}
$$

\section{Results}

Prediction of porcine stress and meat quality

Table 1 shows the combined effects of the studied variables on porcine stress and meat quality. The former was evaluated by blood CK activity, serum values and carcass temperature, while the latter was estimated by muscle glycogen, lactate and $\mathrm{pH}_{1}$ value. Thus the coefficient of determination $\left(\mathrm{R}^{2} 100\right)$ of the prediction equations was highest for carcass temperature $(62.7 \%)$, serum lactate $(61.0 \%)$ and glucose $(60.7 \%)$, and log CK at exsanguination $(57.1 \%)$. Whereas $\mathrm{R}^{2} 100$ decreased for muscle lactate (35.3 \%) and glycogen $(28.5 \%)$ serum glycerol $(22.7 \%)$ and $\mathrm{pH}$ $(19.7 \%)$, and log CK during unloading $(16.4 \%)$. The combined effects of the independent variables of the prediction equations are discussed below.

\section{Selection phase}

Table 2 shows the blood characteristics and the carcass traits studied in the three selection phases. The occurrence of reactors was $0,7.6$ and $4.2 \%$ in the first, second and last selection, respectively. No significant differences were found between the three phases in $\log$ CK at exsanguination that was one of the most contributing components for carcass temperature (partial $\mathrm{R}^{2} 100=12.9 \%$, Table 1).

Pigs of the first selection were stressed least. Thus they had the lowest CK values and the lowest content of muscle lactate. In addition, they had a moderate $\mathrm{pH}$ fall in the LD muscle 45 min p.m. that made them most acceptable for meat products manufacture. This was based on the fact that carcasses which had a fast $\mathrm{pH}$ fall 45 min p.m. developed PSE meat, whereas those with a slow $\mathrm{pH}$ fall could develop dark, firm and dry (DFD) meat in higher frequencies than those with a moderate $\mathrm{pH}$ fall. Actually, our unpublished results indicated that about $20 \%$ of the carcasses with $\mathrm{pH}_{1}$ values over 6.4 developed DFD in the LD next day. 
Table 1. The best stepwise regression modelsa for predicting the characteristics of porcine stress and meat quality.

\begin{tabular}{|c|c|c|}
\hline Prediction equations ${ }^{b}$ & $\mathrm{R}^{2} 100$ & $D^{d}$ \\
\hline $\begin{array}{l}\text { Log CK during unloading }= \\
2.782-0.159 \mathrm{LT}-0.129 \mathrm{TT}+0.327 \mathrm{TD}+0.141 \log \mathrm{CKF}\end{array}$ & 16.4 & $4 / 88$ \\
\hline $\begin{array}{l}\text { Log CK at exsanguination }= \\
\quad-9.933-0.308 \mathrm{LT}+0.652 \mathrm{CT}_{0}+0.27 \mathrm{SGL}-0.288 \mathrm{MG}_{0}+0.218 \log \mathrm{CKU}\end{array}$ & 57.1 & $5 / 47$ \\
\hline $\begin{array}{l}\text { Serum glucose }= \\
\quad 1.027-0.164 \mathrm{TD}+0.647 \mathrm{SL}-0.201 \log C K E\end{array}$ & 60.7 & $3 / 86$ \\
\hline $\begin{array}{l}\text { Serum glycerol }= \\
\quad-19.974-0.378 \mathrm{TT}+0.246 \mathrm{SL}+0.189 \mathrm{SpH}+0.242 \log \mathrm{CKE}\end{array}$ & 22.7 & $4 / 85$ \\
\hline $\begin{array}{l}\text { Serum lactate }= \\
\quad-0.521+0.22 \mathrm{FD}+0.665 \mathrm{SG}+0.154 \mathrm{SGL}+0.13 \log \mathrm{CKF}\end{array}$ & 61.0 & $4 / 85$ \\
\hline $\begin{array}{l}\text { Serum } \mathrm{pH}= \\
\quad 8.03+0.138 \mathrm{TT}+0.167 \mathrm{TD}+0.193 \mathrm{SGL}-0.318 \mathrm{SL}\end{array}$ & 19.7 & $4 / 85$ \\
\hline $\begin{array}{l}\text { Carcass temperature }= \\
\quad 35.331+0.40 \mathrm{LT}+0.501 \mathrm{TT}+0.329 \log \mathrm{CKE}\end{array}$ & 62.7 & $3 / 53$ \\
\hline $\begin{array}{l}\text { Glycogen of } \mathrm{LD}= \\
\quad 6.435-0.241 \mathrm{TT}-0.222 \mathrm{FD}-0.189 \mathrm{ML}_{0}+0.202 \mathrm{CW}-0.195 \log C K E\end{array}$ & 28.5 & $5 / 89$ \\
\hline $\begin{array}{l}\text { Lactate of LD }= \\
\quad 7.907+0.49 \mathrm{TD}-0.216 \mathrm{ST}-0.189 \mathrm{MG}_{0}-0.203 \mathrm{pH}_{1}+0.173 \mathrm{CC}\end{array}$ & 35.3 & $5 / 89$ \\
\hline
\end{tabular}

a Regression models have significant $F$-values $(P<0.01)$.

b Abbreviations given in text.

c Coefficient of determination $\times 100$

d Degrees of freedom.

Table 2. Mean values of studied variables in three selection phases.

\begin{tabular}{|c|c|c|c|c|c|}
\hline \multirow[t]{2}{*}{ Trait } & & \multicolumn{3}{|c|}{ Selection phase } & \multirow[t]{2}{*}{ SEM } \\
\hline & & First & Second & Last & \\
\hline Log CK on farm, & $\mathrm{U} / \mathrm{I}$ & 3.0 & 3.2 & 3.2 & 0.03 \\
\hline Log CK during unloading, & $\mathrm{U} / 1$ & $3.0^{\mathrm{a}}$ & $3.4^{\mathrm{b}}$ & 3.2 & 0.04 \\
\hline Log CK at exsanguination, & $\mathrm{U} / \mathrm{I}$ & 3.2 & 3.4 & 3.5 & 0.05 \\
\hline Serum glucose, $\mathrm{mmol} / 1$ & & $5.6^{\mathrm{a}}$ & $5.0^{\mathrm{a}}$ & $7.8^{b}$ & 0.05 \\
\hline Serum glycerol, mmol/1 & & 0.5 & 0.5 & 0.6 & 0.003 \\
\hline Serum lactate, $\mathrm{mmol} / \mathrm{l}$ & & $13.3^{\mathrm{a}}$ & $12.2^{\mathrm{a}}$ & $16.7^{b}$ & 0.06 \\
\hline Serum pH & & 8.0 & $8.1^{\mathrm{a}}$ & $7.8^{\mathrm{b}}$ & 0.03 \\
\hline Carcass temperature, ${ }^{\circ} \mathrm{C}$ & & $39.3^{a}$ & 38.6 & $38.1^{b}$ & 0.13 \\
\hline Glycogen of LD, $\mu \mathrm{mol} / \mathrm{g}$ & & $27.2^{\mathrm{a}}$ & $30.2^{a}$ & $23.5^{b}$ & 0.20 \\
\hline Lactate of $\mathrm{LD}, \quad \mu \mathrm{mol} / \mathrm{g}$ & & 38.9 & 45.6 & 45.6 & 0.11 \\
\hline Fasting time, h & & $22.3^{a}$ & $17.5^{b}$ & $21.2^{\mathrm{a}}$ & 0.52 \\
\hline $\mathrm{pH}_{1} \leq 5.8, \%$ & & 8.3 & 22.7 & 8.3 & - \\
\hline $5.8<\mathrm{pH}_{1} \leq 6.4, \%$ & & 66.7 & 45.5 & 58.4 & - \\
\hline $6.4<\mathrm{pH}_{1}, \quad \%$ & & 25.0 & 31.8 & 33.3 & - \\
\hline Best grading class, $\quad \%$ & & 8.3 & 38.5 & 45.8 & - \\
\hline Good grading class, $\%$ & & 50.0 & 24.6 & 41.7 & - \\
\hline Poor grading class, $\%$ & & 41.7 & 36.9 & 12.5 & - \\
\hline Carcass hot weight, $\mathrm{kg}$ & & 74.7 & 77.5 & 74.1 & 0.79 \\
\hline Number of pigs & & 12 & 66 & 24 & - \\
\hline
\end{tabular}

a, b Means within a row with different superscripts are significantly different $(\mathrm{P}<0.05)$. 
The pigs of the second selection were under greatest stress during transportation (table 2). Consequently, they had the highest CK activities after transport and elevated muscle lactate content. However, these animals had the greatest muscle glycogen content which might be caused by their shortest fasting time and smallest increase in CK values during lairage. Actually, fast duration and carcass hot weight accounted for 8.4 and $2.6 \%$ of the variation in muscle glycogen, respectively (Table 1). On the other hand, selection phase had no significant influence on carcass weight. Furthermore, the pigs of the second selection had the fastest $\mathrm{pH}$ fall in the LD muscle 45 min p.m. that explained their highest PSE frequency of $22.7 \%$. In addition, the percentage of the carcasses of the best grading class i.e. the highest lean meat content was greater in these pigs than in those of the first selection.
The pigs of the last selection were stressed most severely on the journey from producer up to the point of stunning (table 2). Therefore they had the highest CK values at farm and slaughter and the highest content of serum glucose, glycerol and lactate that led to the lowest serum $\mathrm{pH}$ value.

Among the variables listed in Table 1, serum lactate was the most predictive one for serum glucose $(43.6 \%)$ and $\mathrm{pH}$ value $(9.4 \%)$, while serum glucose provided the best single estimate of serum lactate $(39.4 \%)$. Furthermore, the pigs of the last selection had the lowest content of muscle glycogen (Table 2 ). This could be explained by fast duration $(8.4 \%)$ and by $\log$ CK at exsanguination $(3.5 \%)$. However, muscle lactate did not vary significantly between the selection phases. Moreover, the pigs of the last selection had the slowest $\mathrm{pH}$ fall in the LD muscle $45 \mathrm{~min}$ p.m. which accounted for their low PSE fre-

Table 3. Effect of fasting time on porcine stress and meat quality.

\begin{tabular}{|c|c|c|c|c|c|c|c|c|c|}
\hline \multirow[t]{2}{*}{ Trait } & & \multicolumn{8}{|c|}{ Fasting time, h } \\
\hline & & 7 & 17 & 18 & 19 & 21 & 24 & 27 & SEM \\
\hline Log CK on farm, & $\mathrm{U} / \mathrm{l}$ & 3.2 & $3.4^{\mathrm{a}}$ & 3.2 & 3.1 & $3.0^{b}$ & $3.3^{\mathrm{a}}$ & 3.1 & 0.03 \\
\hline Log CK during unloading, & $\mathrm{U} / \mathrm{I}$ & 3.3 & $3.4^{\mathrm{a}}$ & $3.5^{\mathrm{a}}$ & 3.4 & $3.1^{\mathrm{b}}$ & 3.3 & 3.2 & 0.04 \\
\hline Log CK at exsanguination, & $\mathrm{U} / 1$ & 3.5 & 3.5 & $3.7^{\mathrm{a}}$ & $3.4^{b}$ & $3.2^{\mathrm{b}}$ & $3.2^{\mathrm{b}}$ & $3.6^{\mathrm{a}}$ & 0.05 \\
\hline Change in log $\mathrm{CK}^{*}, \%$ & & 5.9 & 5.5 & $16.3^{\mathrm{a}}$ & 8.2 & 6.4 & $-2.2^{b}$ & $15.2^{\mathrm{a}}$ & 1.68 \\
\hline \multicolumn{10}{|l|}{ Serum: } \\
\hline glucose, $\mathrm{mmol} / \mathrm{l}$ & & 5.6 & $5.0^{\mathrm{a}}$ & $4.4^{\mathrm{a}}$ & $5.6^{\mathrm{a}}$ & $7.8^{b}$ & $7.2^{\mathrm{b}}$ & 6.1 & 0.05 \\
\hline lactate, $\mathrm{mmol} / \mathrm{l}$ & & 12.2 & $13.3^{\mathrm{a}}$ & $12.2^{\mathrm{a}}$ & $12.2^{\mathrm{a}}$ & 15.6 & $16.7^{\mathrm{b}}$ & 15.6 & 0.06 \\
\hline $\mathrm{pH}$ & & 7.9 & $7.9^{\mathrm{a}}$ & 8.1 & 8.1 & $7.9^{\mathrm{a}}$ & 7.9 & $8.2^{\mathrm{b}}$ & 0.03 \\
\hline Carcass temperature, ${ }^{\circ} \mathrm{C}$ & & 38.8 & $38.0^{\mathrm{a}}$ & 38.9 & $38.3^{\mathrm{a}}$ & $37.6^{a}$ & $38.2^{\mathrm{a}}$ & $39.4^{b}$ & 0.13 \\
\hline Glycogen of LD, $\mu \mathrm{mol} / \mathrm{g}$ & & $34.0^{\mathrm{ab}}$ & $37.0^{\mathrm{a}}$ & $25.3^{\mathrm{bc}}$ & $30.2^{\mathrm{ab}}$ & $27.8^{b}$ & $24.1^{\mathrm{bc}}$ & $18.5^{\mathrm{c}}$ & 0.20 \\
\hline Lactate of LD, $\mu \mathrm{mol} / \mathrm{g}$ & & 41.1 & 48.9 & 46.7 & $42.2^{\mathrm{a}}$ & $35.6^{a}$ & $52.2^{\mathrm{b}}$ & $51.1^{b}$ & 0.11 \\
\hline $\mathrm{pH}_{1} \leq 5.8, \%$ & & 9.1 & 25.0 & 5.0 & 21.7 & 8.3 & 41.7 & 16.7 & - \\
\hline $5.8<\mathrm{pH}_{1} \leq 6.4, \%$ & & 54.5 & 33.3 & 50.0 & 30.4 & 83.4 & 58.3 & 66.7 & - \\
\hline $6.4<\mathrm{pH}_{1}$ & & 36.4 & 41.7 & 45.0 & 47.9 & 8.3 & 0 & 16.6 & - \\
\hline \multicolumn{10}{|l|}{ Grading class: } \\
\hline best, $\%$ & & 36.4 & 25.0 & 47.4 & 30.4 & 33.3 & 33.3 & 50.0 & - \\
\hline good, $\%$ & & 18.2 & 41.6 & 26.3 & 39.1 & 16.7 & 41.7 & 33.4 & - \\
\hline poor, $\%$ & & 45.4 & 33.4 & 26.3 & 30.5 & 50.0 & 25.0 & 16.6 & - \\
\hline Carcass hot weight, $\mathrm{kg}$ & & $76.6^{a}$ & $82.2^{\mathrm{b}}$ & $79.1^{\mathrm{a} b}$ & $76.3^{a}$ & $75.3^{a}$ & $63.9^{\circ}$ & $77.6^{\mathrm{ab}}$ & 0.79 \\
\hline Number of pigs & & 12 & 12 & 20 & 23 & 12 & 12 & 12 & - \\
\hline
\end{tabular}

a, b, c Means within a row with different superscripts are significantly different $(\mathrm{P}<0.05)$.

* Change in $\log C K=100 \times \frac{\log C K \text { at exsanguination }-\log C K \text { on farm }}{\log C K \text { on farm }}$ 
quency. Finally, the percentage of the carcasses of the best grading class was highest in this group.

\section{Fasting time}

The effects of fasting time on some blood characteristics and carcass traits are presented in table 3. The occurrence of reactors was 9.1, $0,0,17.4,0,0$ and $8.3 \%$ in the pigs fasted for $7,17,18,19,21,24$ and $27 \mathrm{~h}$, respectively. Fast duration was one of the most contributing components for serum lactate $(17.6 \%)$ and muscle glycogen $(8.4 \%)$. While in the other models listed in Table 1, fasting made non-significant contributions.

The linear effect of fast duration on the studied traits (Table 3 ) was evaluated by simple regression analysis. Fasting time had a significant positive influence on serum lactate and glucose, and muscle lactate content. Consequently, it was estimated that a prolongation of fast duration (FD) from 6 to $18 \mathrm{~h}$ increased the level of serum lactate (SL) from 8.0 to $12.9 \mathrm{mmol} / \mathrm{l}$, glucose (SG) from 4.0 to $6.1 \mathrm{mmol} / \mathrm{l}$ and muscle lactate $\left(\mathrm{ML}_{0}\right)$ from 39.2 to $44.6 \mu \mathrm{mol} / \mathrm{g}$. The respective equations were $\mathrm{SL}=5.548+0.407 \mathrm{FD}\left(\mathrm{R}^{2} 100=17 \%\right.$, $\mathrm{P}<0.001), \mathrm{SG}=2.997+0.171 \mathrm{FD}\left(\mathrm{R}^{2} 100=\right.$ $11 \%, \mathrm{P}=0.001)$ and $\mathrm{ML}_{0}=36.507+0.449 \mathrm{FD}$ $\left(\mathrm{R}^{2} 100=4 \%, \mathrm{P}<0.05\right)$.

In contrast, the prolonged fasting time reduced significantly muscle glycogen, $\mathrm{pH}_{1}$ value and carcass hot weight in this study. So an increase in fast from 6 to $18 \mathrm{~h}$ reduced muscle glycogen from 37.9 to $28.8 \mu \mathrm{mol} / \mathrm{g}, \mathrm{pH}_{1}$ value from 6.45 to 6.23 and carcass hot weight from 80.4 to $76.1 \mathrm{~kg}$. In addition, the respective equations were $\mathrm{MG}_{0}=42.473-0.759 \mathrm{FD}$ ( $\left.\mathrm{R}^{2} 100=11 \%, \mathrm{P}=0.001\right), \mathrm{pH}_{1}=6.559-$ $0.018 \mathrm{FD}\left(\mathrm{R}^{2} 100=6 \%, \mathrm{P}<0.05\right)$ and $\mathrm{CW}=$ $82.59-0.341 \mathrm{FD}\left(\mathrm{R}^{2} 100=5 \%, \mathrm{P}<0.05\right)$.

Pigs showed the highest blood $\mathrm{CK}$ values after an 18 or $27 \mathrm{~h}$ fasting period. On the other hand, fast times of $7-27 \mathrm{~h}$ were not significantly related to blood $\mathrm{CK}$, serum glycerol or carcass temperature, however the highest $\mathrm{CK}$ activity and carcass temperature were found after a $27 \mathrm{~h}$ fast period. Furthermore, the fall in the LD muscle pH 45 min p.m. was fastest after a $24 \mathrm{~h}$ fast and slowest after an 18-19 h fast.

\section{Transport}

Table 1 shows that the loading time of day was one of the most contributing variables for $\log$ CK during unloading (3.9 \%) and carcass temperature $(14.6 \%)$. In addition, transport temperature was one of the best predictors of carcass temperature $(35.2 \%)$, muscle glycogen $(10.5 \%)$, serum glycerol $(11.2 \%)$ and $\mathrm{pH}(3.2 \%)$, and log CK during unloading $(1.4 \%)$. Furthermore, transport duration made major contributions of the variation in muscle lactate $(15.7 \%)$, serum glucose $(13.7 \%)$ and $\mathrm{pH}(5.5 \%)$, and $\log \mathrm{CK}$ during unloading $(8.7 \%)$.

The effects of loading time, transport temperature and duration on porcine stress were evaluated by the change in CK activity from the farm up to the unloading (figure 1). In general, pigs were fed a restricted ration twice a day at 8-9 o'clock a.m. and at 2-3 o'clock p.m. Results suggested that pigs were stressed most severely during transport if loaded just before the morning or afternoon feed. In contrast, transport was least stressful when pigs were loaded at 9-10 o'clock a.m. that was between the two feeding periods.

During transport, pigs were stressed significantly if a heavy frost $\left(-20^{\circ} \mathrm{C}\right)$, still more significantly if a small frost $\left(-4^{\circ} \mathrm{C}\right)$ and most significantly in warm weather $\left(15^{\circ} \mathrm{C}\right)$. Whereas, transportation in cool weather $\left(8^{\circ} \mathrm{C}\right)$ was least stressful for pigs (figure 1). These results were supported by the frequency of transport losses. Actually, the mortality was low during a heavy frost $\left(-30\right.$ to $\left.-20^{\circ} \mathrm{C}\right)$, while it increased considerably in cold weather $(-3$ to $0^{\circ} \mathrm{C}$ ), and maximum mortality was found in warm weather $\left(14\right.$ to $\left.24^{\circ} \mathrm{C}\right)$.

In general, increasing transport time resulted in elevated CK values (figure 1). Thus, pigs were stressed least during a trip of $17 \mathrm{~min}$, while maximum stress was found during the 

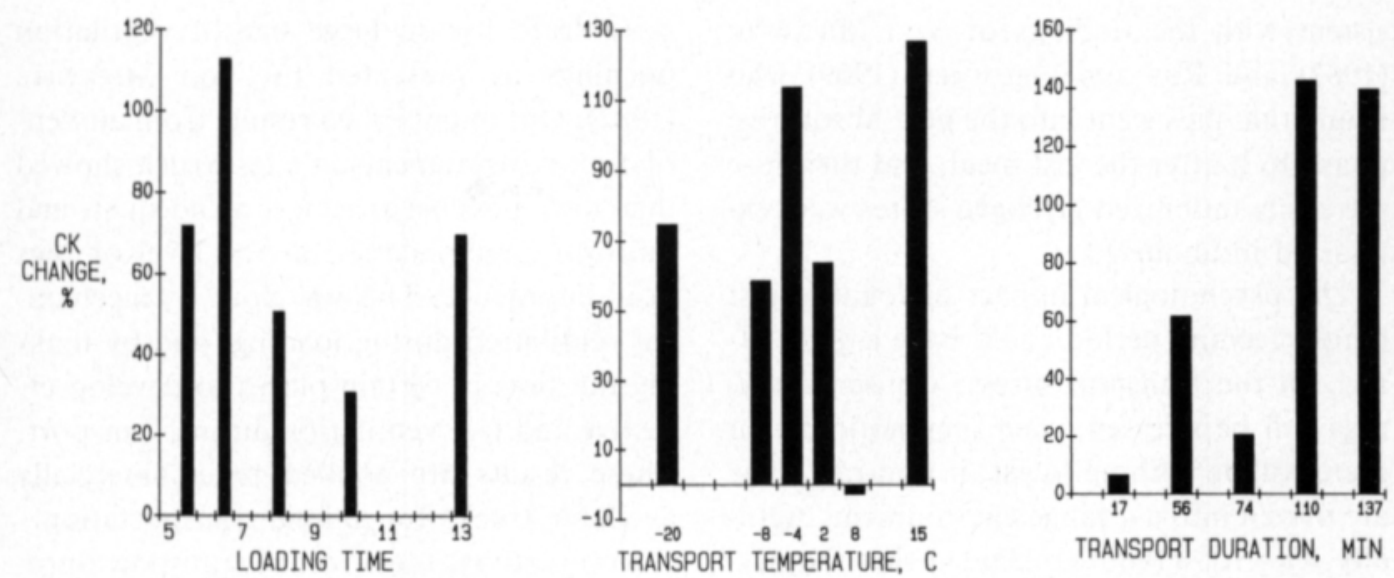

Fig. 1. Effect of loading time of day, transport temperature and duration on the increase of blood creatine kinase (CK) activity.

CK change $(\%)=100 \times \frac{\text { CK during unloading }- \text { CK on farm }}{\text { CK on farm }}$

journeys of 110 and $137 \mathrm{~min}$. An exception to these findings was the low CK change after a journey of $74 \mathrm{~min}$ that could be due to high CK activity of the pigs on farm. On the other hand, mortality was low during the 10-20 min transport, while maximum mortality occurred during the $45-80$ min transportation. However, mortality decreased prominently during the journeys of 120 to $420 \mathrm{~min}$.

\section{Discussion}

The pigs of the first selection were least stress-susceptible and had the best meat quality, however their carcasses had poorer grading class than those of the later selection phases. Whereas, the pigs of the second selection were heavier than the others, in addition, they were most susceptible to the development of PSE at slaughter. The pigs of the last selection were under stress throughout and therefore they had the slowest $\mathrm{pH}$ fall in the LD muscle $45 \mathrm{~min}$ p.m. Moreover, carcasses of this group had the highest percentage of the best grading class.

Results suggested that the best possible pork quality for the meat industry will be obtained when pigs are grown fast and evenly so that there will be no significant differences in liveweights between the animals of the same group. Thus, the psychological impact of selecting pigs in different phases could have a significant effect on the development of porcine stress due to changes in the familiar group. These will result in hierarcial fighting and other negative behavioral changes in the rest of animals.

This study considered the fasting times that are used in commercial practice. Moreover, there will be a trend to shorten the lairage times nowadays, hence fast duration will also be reduced. This is made possible by the breeding activities which improved significantly the stress-resistance of the Finnish pigs since 6 years.

In this work, muscle $\mathrm{pH}_{1}$ value, glycogen and lactate content suggested that the most acceptable pork quality for meat products was obtained after a fast of $6-7 \mathrm{~h}$ when pigs were fed twice a day. Because of increased risk of transport losses due to feeding, the last meal should be lighter by half than usual, in addition, pigs should have free access to drink water. Furthermore, it was not recommended to fast pigs for $17-27 \mathrm{~h}$ due to overnight holding which had a negative effect on muscle lactate and glycogen content. This result was con- 
sistent with the findings of Von MiскwITZ (1982) and Rils and Grummer (1969) who found that pigs went into the post-absorptive phase $16 \mathrm{~h}$ after the last meal, and therefore the easily mobilized glycogen stores were exhausted in about $20 \mathrm{~h}$.

The psychological impact of loading just before feeding period could have a great effect on the transport stress. Consequently, pigs will be stressed when they noticed that there will be nothing to eat, in contrast, they are driven into a strange environment. Actually, Gonyou (1986) concluded that the psychological impact of the situation is more important in determining the response than the physical.

The present results suggested that the high transport losses and $\mathrm{CK}$ values in cold weather $\left(-6-0^{\circ} \mathrm{C}\right)$ occurred due to fluctuating temperature and due to closed ventilation slots which were not opened until air temperature raised over $0^{\circ} \mathrm{C}$. Therefore, the improved cooling of pigs due to better ventilation could decrease porcine stress at temperatures of 5 to $10^{\circ} \mathrm{C}$. Above external temperatures of $10^{\circ} \mathrm{C}$ pigs were not able to maintain constant body temperature during trucking which accounted for the heat stress that led to increased CK activity and mortality during transport.

The weather is considerably colder in Finland than in Central Europe, therefore it is not possible to use so large size of ventilation openings as presented by Von Mıскwitz (1982). Our unpublished results from air ventilation measurements in a test truck showed that it was possible to achieve an adequate and uniform air circulation at the level of pigs head in practice. This was done by mechanical ventilation during loading, and by making the slots in certain places to develop effective and free ventilation during transport. These results are applied to commercially available trucks for animal transportation.

In this study, the effect of transport duration on mortality was consistent with the increase in CK activity during transport. Thus, it was found that mortality was low during the short transport times of $10-25 \mathrm{~min}$, while maximum losses occurred during the $45-80$ min transport. These results suggested that the most stress-sensitive pigs will already die during a relative short 45 min transport, whereas stress resistant animals will survive and showed an increased CK activity during unloading.

Acknowledgements. The author wishes to thank producers, truck drivers, delivery and abattoir personnel of the Itikka Lihabotnia and LSO Food for co-operation. Thanks are also given to Mrs. Kirsti Rantanen for laboratory analysis. This investigation was supported by the Finnish Academy.

The Hague, Curr. Topics Vet. Med. Anim. Sci. 18: 45-54.

Nielsen, N.J. 1981. The effect of environmental factors on meat quality and on deaths during transportation and lairage before slaughter. In Porcine Stress and Meat Quality - causes and possible solutions to the problems, (Froystein, T., Slinde, E. \& Standal, N., Eds.), Agr. Food Res. Society, Norway, 287-297.

Pospiech, E., Dzierzynska-cybulko, B., Maruniewicz, W. \& Darul, W. 1981. Pre-slaughter weight of pigs and occurrence of PSE and DFD meat. Proc. 27th Eur. Meet. of Meat Res. Workers, Vienna, 38-41. Riıs, P.M. \& Grummer, R.H. 1969. The relationship be- 
tween glucose and fatty acid metabolism in pigs under various feeding conditions. Acta Agric. Scand. 19: 11-17.

Wiluams, J.M. 1985. Causes and effects of porcine stress syndromes. The Veterinary Annual, 25th Issue, Bristol, Scientechnica, 175-179.

Ms received July 4, 1988

\section{SELOSTUS}

\section{Karsintavaiheen, paaston ja kuljetuksen \\ vaikutus sian stressaantumiseen ja PSE-lihan muodostumiseen}

\author{
Markku Honkavaara \\ Lihateollisuuden Tutkimuskeskus, \\ PL 56, 13101 Hämeenlinna
}

Työssä tutkittiin karsintavaiheen, paaston ja kuljetuksen vaikutusta sian stressaantumiseen ja PSE-lihan muodostumiseen.

Alkukarsinnassa sikojen veren kreatiinikinaasi- (CK-) aktiivisuus oli alhaisin ja tăllöin niissả oli văhiten PSE:tă. Sen sijaan karsitut siat stressaantuivat kuljetuksessa eniten, niiden PSE-\% oli korkein. Lopputyhjennyksessă sikojen CK-aktiivisuus oli korkea tilalta pistoon, edelleen niiden pitkän selkälihaksen $\mathrm{pH}$ laski muita hitaammin 45 min postmortem. Ruhon lihaprosentti oli korkein lopputyhjennyksen ja alhaisin alkukarsinnan sioissa.

Kahdesti päivãssä ruokittujen sikojen paastotessa 6-
$7 \mathrm{~h}$ ennen teurastusta niiden lihassa oli niin paljon glykogeeniă ja niin văhăn maitohappoa, ettă lihan laatu oli moitteeton. Sikojen lepo yön yli teurastamon navetassa alensi ruholihan glykogeenitasoa ja lisäsi sen maitohappopitoisuutta.

Kuljetus stressasi sikoja eniten silloin, kun ne lastattiin juuri ennen aamu- tai iltaruokintaa tai jos eläimet kuljetettiin lämpimällă ilmalla (yli $10^{\circ} \mathrm{C}$ ). Sikojen autokuolleisuus ja veren CK-aktiivisuus kuljetuksessa olivat korkeimmillaan samalla ulkolạmpötila-alueella. Mitā pitempi oli kuljetusaika sită enemmăn veren CK-aktiivisuus kohosi tilalta teurastamoon. 